\title{
Упоров И.В.
}

\section{Правовое регулирование назначения и исполнения уголовного наказания в виде отдачи на время в исправительные арестантские роты гражданского ведомств в Российской империи}

\author{
Uporov I.V. \\ Legal regulation of appointment and execution of criminal \\ punishment in the form of return on time in correctional convict \\ company Civil authorities in the Russian Empire
}

В статье раскрываются особенности назначения и исполнения уголовного наказания в виде отдачи в исправительные арестантские роты гражданского ведомства в Российской империи. Отмечается, что это было довольно суровое наказание. Одновременно имело место подробное его регулирование как в уголовном, так и уголовноисполнительном законодательстве, что определенным образом усиливало правовые гарантии арестантов

Ключевые слова: уголовное наказание, закон, арестантские роты, взыскание, исправление, отряд исправляющихся, отряд испытуемых, крепостная рота

\section{Упоров Иван Владимирович \\ Доктор исторических наук, кандидат юридических наук, профессор \\ Краснодарский университет МВД России \\ г. Краснодар, ул. Ярославского, 122}

The article describes the features of the destination and the execution of criminal penalties in the form of return to the penitentiary convict companies of civil authorities in the Russian Empire. It is noted that it was quite a severe punishment. At the same time there has been a detailed its suspension control ing both in the criminal and criminal-executive legislation, which in certain ways strengthened legal guarantees prisoners

Key words: criminal penalties, law, convict company, recovery, repair, detachment corrected, the test squad, serf company

\footnotetext{
Uporov Ivan Vladimirovich

Doctor of Historical Sciences, Candidate of Law, Professor Krasnodar university of MVD Russia Krasnodar, Yaroslavl st., 122
}

Отдача на время в исправительные арестантские роты гражданского ведомства являлось одним из видов лишения свободы, предусмотренного Уложением о наказаниях уголовных и исправительных 1845 года [1], где оно впервые было отрегулировано на системном уровне. В перечне уголовных наказаний арестантские роты занимали по степени суровости третье место (после смертной казни и ссылки в каторжную работу). Это наказание влекло за собой потерю всех особенных прав и преимуществ лично или же по состоянию или званию присвоенных (п. І ст. 34 Уложения). Кроме того, реализация этого наказания для 
лиц, не изъятых от телесных наказаний, начиналась с телесных наказаний в зависимости от срока присуждения к работам в исправительных арестантских ротах (ст.34, 35): на время от восьми до десяти лет - наказание розгами от 90 до 100 ударов (степень 1); на время от шести до восьми лет - от 80 до 100 ударов (степень 2); на время от четырех до шести лет - от 70 до 80 ударов (степень 3); на время от двух до четырех лет - от 60 до 70 ударов (степень 4); на время одного года до двух лет - от 50 до 60 ударов (степень 5). Впоследствии, после 1863 года, телесные наказания были отменены; изменилось и само название этого вида лишения свободы - в Уложении о наказаниях уголовных и исправительных в редакции 1885 года оно было обозначено как "отдача на время в исправительное арестантское отделение" [2].

Согласно ст.48 Уложения 1845 года присужденные к отдаче на время в исправительные арестантские роты могли быть "употребляемы в городские и всякие другие работы". Они сохраняли свои семейные права и права на прежнюю собственность, однако "дворяне, как уже лишенные особенных преимуществ, сему состоянию предоставленных, не могли продолжать владеть своим дворянским имуществом". По освобождении от работ в исправительных арестантских ротах осужденные отдавались на четыре года под особый надзор местной полиции, или же их обществ или помещиков, если они не возражали принять их. В продолжение этого времени бывшие осужденные не вправе были менять места жительства и удаляться из них без дозволения полиции, общества или помещика; иногородним пребывание в столицах и губернских городах также воспрещалось.

Осужденные к этому наказанию могли быть, по требованию инженерного начальства, отсылаемы в арестантские крепостные роты (в исправительные отряды) с уменьшением определенного судом числа лет работы таким образом, чтобы за один год работ в арестантских ротах гражданского ведомства полагалось девять месяцев работ в арестантских крепостных ротах. Из мест, где исправительные арестантские роты гражданского ведомства еще не были учреждены, осужденные помещались в ближайшие арестантские роты гражданского ведомства либо ближайшие же крепостные арестантские роты. Присужденные в арестантские роты на краткие сроки, то есть от одного горда до двух лет или от двух до четырех лет, могли быть, "в случае большой отдаленности от места, где оные учреждены", помещаемы в рабочие дома, но на более продолжительные сроки, считая за каждый год работы в арестантских ротах полтора года в рабочем доме. Те, кто "по старости, дряхлости и иным причинам" к работам в арестантских ротах не способны, а равно и женщины, всегда отдавались вместо этого в рабочие дома, и также на более продолжительные сроки (ст.83).

По поводу данной замены видов лишения свободы сразу заметим, что, по нашему мнению, она явно противоречила принципу справедливости, поскольку условия содержания в арестантских ротах и рабочих домах отличались не столь сильно, чтобы в полтора раза увеличивать срок в последних, тем более, что общий характер наказания был один и тот же: осужденные содержались в запираемых помещениях; равным образом это касается и замены арестантской роты 
гражданского ведомства на крепостную роту - условия в них также не отличались значительным образом.

Дальнейшее развитие институт отдачи в арестантские роты гражданского ведомства находит уже в Своде учреждений и уставов о содержащихся под стражею [3]. Согласно содержащимся в этом акте нормам арестантские роты гражданского ведомства состояли в ведомстве Главного управления путей сообщения и публичных зданий, которое заведовало ротами посредством начальников губерний и губернских строительных и дорожных комиссий; военное управление каждой ротой сосредоточивалось в лице ротного командира; ближайший надзор за ходом и успехами нравственного исправления арестантов вверялся тюремным комитетам Общества попечительного о тюрьмах.

Содержание в арестантских ротах гражданского ведомства разделялось на два разряда. К первому разряду относились осужденные за преступления и бродяги, "не помнящие родства"; ко второму причислялись лица, водворенные за неплатежи недоимок и по приговорам обществ для исправления, а также беглые - до собрания о них необходимых справок. Содержание арестантов этих разрядов предусматривалось раздельное. В свою очередь каждый разряд делился на отделения, причем обращалось внимание "на лета арестантов, так, чтобы не помещались в одном и том же отделении люди слишком разных возрастов". Холостым арестантам запрещалось вступать в браки, а женатым жить с женами. Попечение о занятии арестантов работами возлагалось на строительные комитеты или комиссии. Наблюдение за обучением мастерствам и содействие к успешному приисканию средств для сего обучения поручалось также строительным комитетам или комиссиям, а также особым попечителям.

Довольно значительное внимание (ст. 1031-1046 Свода учреждений и уставов о содержащихся под стражею) уделялось вопросам привлечения арестантов к труду. Указывалось, в частности, что они должны были употребляться преимущественно в тех городах, где были учреждены арестантские роты, однако при их недостатке или особенной надобности с разрешения начальников губерний могли использоваться на работах вне города, но на расстоянии не свыше девяти верст. Арестанты могли трудоустраиваться и внутри расположения арестантских рот - как на хозяйственных работах по обслуживанию места лишения свободы, так и на выполнении частных заказов, однако строго воспрещалось их употреблять "по письменным делам".

При наряде арестантов на работы должны были наблюдаться, чтобы переход от работ тяжелых к работам менее трудным представлялся преимущественно тем, которые заслуживают этого по своему поведению или успехами или же для которых "это необходимо по слабости их сил". Несовершеннолетние (до 17 лет) на тяжелые работы не выводились, они лишь обучались «мастерствам». Устанавливалось шесть рабочих дней, причем в субботы работы длились только до обеда. Размер поденной заработной платы определялся ежегодно строительным комитетом или комиссией с утверждением начальником губернии из расчета уменьшения ее на 30-30\% по сравнению с "местной ценой обыкновенного рабочего дня". 
Две трети арестантского заработка обращались в "пополнение земского сбора", за счет которого содержались арестантские роты; одна треть оставалась в роте - для улучшений условий содержания тех арестантов, которые показывают лучшие результаты в исправлении, а также на пособия освобождающимся. К доходам арестантских рот добавлялись также подаяния, собираемые в кружках, выставленных у дверей занимаемого ротой здания и в одной из местных церквей; причем эти средства можно было использовать только для устройства больницы и для пособий освобождающимся. На руки деньги арестантам выдавать было строго запрещено.

Законом предусматривалось содержание арестантов в острогах. Начальнику рот вменялось в обязанность заботиться о нравственном их исправлении. Для этих целей при арестантских ротах состоял священник в качестве духовного отца и наставника роты. Ежедневно, утром и вечером, читались молитвы, в праздничные дни арестанты выводились в церкви к литургии. Для возбуждения и поддержания в арестантах стремления к исправлению предписывалось "время от времени читать им наставления об обязанностях христианина и подданного, о степенях наказаний и постепенном облегчении участи раскаивающегося в своей вине преступника, указывая, когда нужно, на статьи законов, коими определяются сии облегчения для арестантов, отличающихся хорошим поведением". В конце каждого месяца ротный командир должен был делать общее заключение о поведении каждого арестанта, в обязательном порядке записывая взыскания, если они на него накладывались.

Арестанты первого разряда, отличившиеся в течение двухлетнего пребывания в роте добрым поведением, исполнением обязанностей веры и прилежанием к труду, или успехи в изучении мастерства, причислялись в особый отряд «исправляющихся»; арестанты второго разряда в этот отряд могли попасть спустя год. Для арестантов отряда исправляющихся предусматривалась особая одежда, они выводились на работы отдельно от других, и стража при них могла быть уменьшена; телесным наказаниям они подвергались не иначе как с разрешения Попечителя роты и ротного командира. Отличившиеся поведением арестанты отряда исправляющихся "по прошествии некоторого времени, нужного для испытания их", могли по поручению ротного командира осуществлять надзор за другими арестантами (следует заметить, что этот подход использовался также в местах лишения свободы советского государства).

Среди этих и других преимуществ, предусмотренных для отряда исправляющихся, наиболее существенное заключалось в льготном исчислении срока лишения свободы, а именно: десять месяцев пребывания в отряде исправляющихся считались за год пребывания в арестантской роте. Назначение в отряд исправляющихся производилось по общему совещанию и постановлению попечителей, духовного отца роты и ротного командира, с утверждения строительного командира или комиссии, то есть решение принималось коллегиально, что говорит о его важности.

В следующем блоке норм Свода в отношении арестантских рот регламентировались меры взыскания, применяемые к арестантам. Так, арестант, изобли- 
ченный в двухкратном побеге или покушении к побегу, уже не мог быт переведен в отряд исправляющихся. Если арестант после поступления в роту наказывался более двух раз телесно, то в отряд исправляющихся он переводился не ранее чем через два года после последнего такого наказания. За плохое поведение, если арестант предавался снова "порокам" (в Своде не указывается, каким именно), он возвращался в отряд "обыкновенных арестантов", а вернуться в отряд исправляющихся мог не ранее чем через три года. За нарушения режима ротное начальство могло наложить на арестантов следующие взыскания: за "маловажные" проступки: 1) выговор в присутствии других; 2) арест в темной камере на двое суток; 3) лишение горячей пищи на время от двух до четырех дней; за проступки, "которые более важны": 4) наказание розгами до 30 ударов. За более весомы нарушения могли применяться: 1) усиление телесного наказания до 100 ударов розгами; 2) бритье половины головы; 3) закование на время в кандалы.

За всякое, более одного раза, наказание усиленными мерами виновные оставались в арестантской роте сверх назначенного по приговору времени еще на 6 месяцев. Данная норма является исключительной; по сути дела здесь судебный принцип заменяется административным (данный принцип встречается в Своде учреждений и уставов о содержащихся под стражею и в отношении других видов лишения свободы). В последующем подобных нормативных положений не включалось ни в один уголовно-правовой, уголовно-процессуальный и уголовно-исполнительный правовой акт. Не характерна эта норма и для самого Свода учреждений и уставов о содержащихся под стражею, в связи с чем ее появление мы считаем случайным.

Наказание в виде отдачи в арестантскую роту гражданского ведомства согласно Уложению о наказаниях уголовных и исправительных назначались за такие преступления, как: похищения, со взломом, из церкви или резницы денег, свеч и других вещей - до 8 лет; лжеприсяга без обдуманного заранее намерения - до 4 лет; воспрепятствование обнародованию высочайших указов, манифестов, законов или других постановлений или же недопущение исполнения соответствующих правительственных распоряжений - до 6 лет; должностные преступления, сопряженные с насилием - до 4 лет; взяточничество - до 6 лет и др.

Обратим внимание на то, что во всех случаях в санкциях соответствующих статей отдаче в арестантскую роту предусмотрены альтернативные виды наказаний; такая альтернативность в предшествовавших уголовно-правовых актах встречалась редко. Анализ Особенной части Уложения 1845 года показывает также, что данное наказание применялось за совершение преступлений самого различного характера.

В целом, как видно, данное наказание характеризуется достаточно суровыми условиями отбывания (содержание в остроге, привлечение к тяжелым работам, применение телесных наказаний, возможность продления срока наказания по внесудебному порядку). При его исполнении по-прежнему отчетливо проявлялось стремление государства использовать труд арестантов для решения прагматических задач, о чем свидетельствует то обстоятельство, что арестантские роты находились в ведении строительных комитетов и комиссий. 
Вместе с тем дальнейшее развитие получили вопросы, связанные с исправлением арестантов, предусматривались более сильные стимулы к правопослушному поведению; определялся круг дисциплинарных взысканий. Стали появляться элементы целенаправленной воспитательной работы (помимо использования священнослужителей), а именно: персоналу предписывалось ежемесячно делать анализ поведения арестантов и записывать выводы в специальный журнал. Кроме того, определенным образом укреплялись гарантии правового положения арестантов, подтверждением чему могли служить нормы о возможности применения ряда взысканий только на основе коллегиальных решений. Вместе с тем в реальности данный вид наказания использовался редко, поскольку специальных помещений для его исполнения было немного, и это наказание во многом по условиям содержаниям было сходно с другими видами наказаниями, которые традиционно давно применялись в России (прежде всего ссылка в каторжную работы, тюремное заключение, арест).

\section{Список используемых источников:}

1. Уложение о наказаниях уголовных и исправительных 1845 года // Российское законодательство Х-ХХ веков. Т.6. М., 1988.

2. Уложение о наказаниях уголовных и исправительных в редакции 1885 года // Свод законов Российской империи. T.XV. СПб., 1914.

3. Свод учреждений и уставов о содержащихся под стражею // Свод законов Российской империи.

T. XIV. СПб., 1857.

(C) 2016, Упоров И.В.

Правовое регулирование назначения и исполнения уголовного наказания в виде отдачи на время в исправительные арестантские роты гражданского ведомств в Российской империи (c) 2016, Uporov I.V. Legal regulation of appointment and execution of criminal punishment in the form of return on time in correctional convict company Civil authorities in the Russian Empire 